\title{
Hayat Bilgisi Öğretim Programı Kazanımlarının Kök Değerler ile İlişkisinin Değerlendirilmesi
}

\author{
Evaluation of the Relationship between Life Science Curriculum Gains and Root Values
}

\section{Anıl ESEMEN1}

1Öğretmen, Milli Eğitim Bakanlığı, anadolu2616@gmail.com, (DD0000-0001-5451-0418

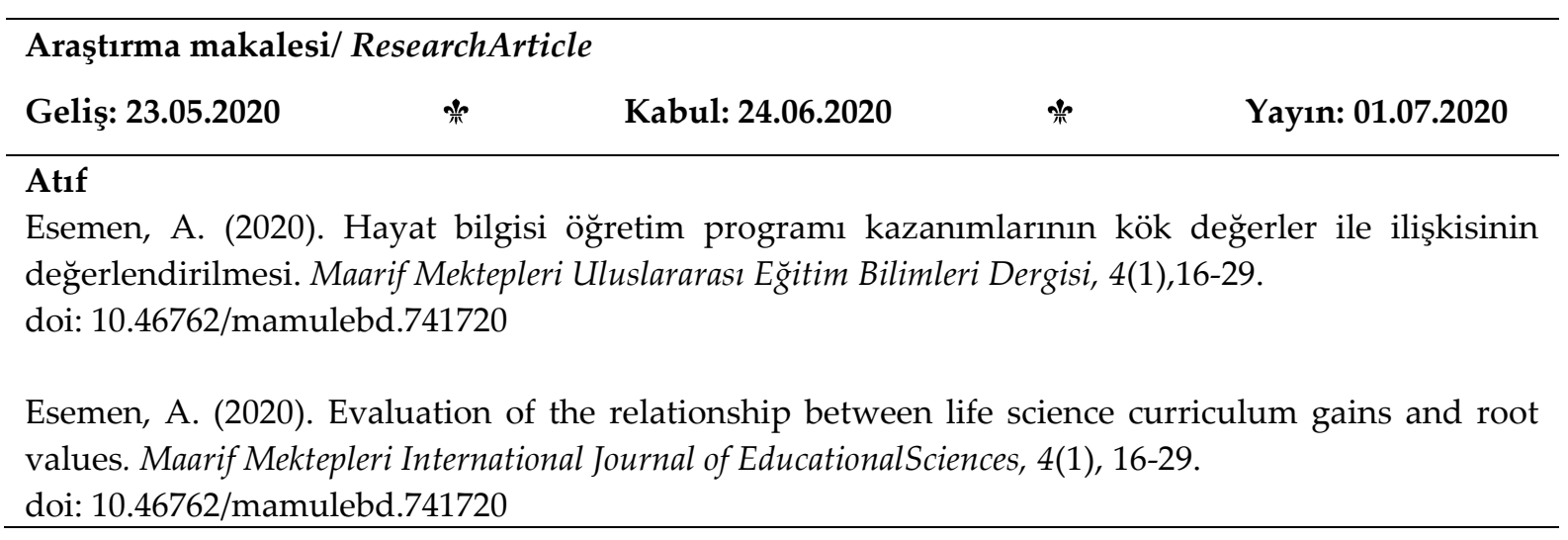

Öz

Bu araştırmada 2018 yılında yenilenen Hayat Bilgisi Öğretim Programı (1, 2. ve 3. sınıf) kazanımlarının öğretim programı içeriğinde belirtilen "kök değerler" (adalet, dostluk, dürüstlük, öz denetim, sabır, saygı, sevgi, sorumluluk, vatanseverlik, yardımseverlik) açısından incelenmesi amaçlanmıştır. Bu amaç doğrultusunda Hayat Bilgisi Öğretim Programı kazanımlarında "kök değerler" in nasıl ve ne düzeyde yer aldığ1 ve öğretim programı üniteleri içerisinde nasıl bir dağılım gösterdiği belirlenmeye çalışılmıştır. Araştırmada doküman inceleme yöntemi analitik araştırma deseni kullanılmıştır. Araştırmanın dokümanı Talim ve Terbiye Kurulu Başkanlığı internet sitesindeki Hayat Bilgisi Öğretim Programıdır. Araştırmanın veri toplama aracı Hayat Bilgisi Öğretim Programı içerisinde belirtilen 10 "kök değer" dir. Hayat Bilgisi Öğretim Programı kazanımları ile ilişkili kök değerlerin sınıflar düzeyinde ve temalar düzeyinde nasıl bir dağılım gösterdiği belirlenmiştir. Yapılan bu araştırmada Hayat Bilgisi Öğretim Programı kazanımlarıyla en fazla ilişkili olan değerlerin "Sorumluluk ve Vatanseverlik" olduğu, en az ilişkili değerlerin ise "Adalet, dostluk ve dürüstlük" olduğu tespit edilmiştir. Ayrıca Hayat Bilgisi Öğretim Programı üniteleri içerisinde kök değerlerin dengeli bir şekilde dağılmadığı 
sonucuna da varılmıştır. Araştırmanın sonuçları doğrultusunda Hayat Bilgisi Öğretim Programında adalet, dostluk ve saygı değerlerinin artırabileceği önerisi getirilebilir.

Anahtar Kelimeler: Kök değerler, ilkokul, hayat bilgisi öğretim programı,

\section{Abstract}

The "rootvalues" (justice, friendship, honesty, self-control, patience, respect, love, responsibility, patriotism, benevolence) stated in thecontent of the curriculum of the Life Science Teaching Program (1st, 2nd and 3rd grade) achievements renewed in 2018 in this research in terms of examination. For this purpose, it has been tried to determine how and at what level "root values" take place in the Life Science Curriculum acquisitions and how they are distributed with in the curriculum units. In the research, document analysis method analytical research design was used. The document of the research is the Life Science Education Program on the website of the Board of Education. The data collection tool of the research is 10 "root values" specified in the Life Science Teaching Program. It has been determined how the root values associated with the Life Science Curriculum achievements show distribution at the level of classes and themes. In this study, it was determined that the values most associated with the Life Science Curriculum achievements were "Responsibility and Patriotism" and the least associated values were "Justice, friendship and honesty". It is also concluded that the root values are not distributed even within the Life Science Teaching Program units. In line with the results of the research, it can be suggested that the values of justice, friendship and respect can be increased in the Life Science Teaching Program.

Keywords: Root values, primary school, life science teaching program,

\section{Giriş}

Arzu edileni ve kıymetli olanı belirleyen değerler (Ulusoy ve Arslan, 2016); insanların olay ve olgular karşısındaki davranışlarını şekillendiren rehberlerdir (Raths, Harmin ve Simon, 1966). Bir başka ifade ile değerler, bireylerin olay ve olgular karşısındaki tutumunu ve tercihini belirlemektedir (Hökelekli, 2010).Bireyi ve toplumu etkileyen iyi değerlerin yanı sıra, toplum içerisinde kötü davranışlar da bulunmaktadır. Bireylerin iyi ve olumlu değerleri kazanması, toplumda yer alan kötü ve olumsuz değerlerin ortadan kalkmasına katkı sağlayacaktır (Turan ve Ulusoy, 2014). Ulusoy ve Dilmaç'a (2014) göre değerler eğitimi ile bireylerin toplum içerisinde huzurlu bir şekilde yaşamasına katkı sağlanırken, toplumun da huzurlu bir şekilde yaşaması amaçlanmaktadır. Ülkeler de sahip oldukları değerleri, vatandaşlarının ve toplumun huzurunu devam ettirmek için, değerler eğitimi yoluyla okullarda öğrencilerine kazandırmaya çalışmaktadır.

Öğrenciler ilk olarak değerleri, planlı ya da plansız, ailelerinde kazanmaktadır. Öğrenciler değerleri ailelerinden sonra planlı bir şekilde okullarda kazanmaktadır. İlkokul kademesi öğrencilerin temel akademik becerileri ve temel değerleri kazanacağı ilk basamaktır (Yaşar, Kasa ve Bayrı, 2015). Hayat Bilgisi dersi ise öğrencilerin ilkokulun ilk üç senesinde karşılaşmış oldukları, kendilerini ve yakın çevrelerini anlamlandırmalarına yardımcı olacak, mihver bir derstir (Şahin, 2009). Topses ve diğerlerine (2001) göre öğrencilere Hayat Bilgisi dersi ile değerler 
kazandırılmaya çalışılmaktadır. Hayat Bilgisi dersi öğrencilerin yaşadıkları çevresinin değerlerini tanımasını sağlayan, bu değerleri öğrencilerin içselleştirmesine yardımcı olan ve bu sayede de öğrencilerin çevrelerine uyumunu kolaylaştıran önemli bir derstir (Bahçe, 2010). Aydın ve Gürler'e (2014) göre öğrencilerin eğitim öğretim sürecinde karşılaştıkları derslerde kazandıkları değerlerin etkililiği bu derslerde edindikleri bilgilerin etkililiğine göre daha uzun olmaktadır. Yani öğrencilerin derslerde öğrendikleri bilgiler öğrenciler tarafından kısa vadede kullanılırken, öğrencilerin bu derslerdeki kazandıkları değerler hayatları boyunca davranışa dönüşmektedir. Eğitim öğretimin ilk üç yılında Hayat Bilgisi derslerinde öğrencilerin kazanacağı değerlerin hayat boyu davranışlarında etkili olması beklenmektedir.

Öğretim programları, okullarda sunulacak olan eğitimin başarısını etkileyen önemli bir unsurdur (Millî Eğitim Bakanlı̆̆g [MEB], 2018). Öğretim programlarının amaçlarından biri de ülkenin kültürel değerlerini korurken bu değerlerin geliştirilmesini sağlamaktır (Özdemir, 2009). Öğretim programları öğrencilerin akademik gelişimine katkı sağlamayı amaçlarken aynı zamanda öğrencilerin iyi değerler kazanmasını da amaçlamaktadır (Jacobs ve Jacobs-Spencer, 2001). Nitekim 2018 yılında yenilenen Hayat Bilgisi dersi öğretim programı içeriğinde "Değerlerimiz" başlığı altında "Eğitim sistemi sadece akademik açıdan başarıll, belirlenmiş bazı bilgi, beceri ve davranışları kazandıran bir yapı değildir. Temel değgerleri benimsemiş bireyler yetiştirmek asli görevidir; yeni neslin değerlerini, alışkanlıklarım ve davranışların etkileyebilmelidir." (MEB, 2018) ifadeleri yer almaktadır. 2018 Hayat Bilgisi dersi öğretim programı içeriğinde tüm eğitim sürecinin nihai gayesi olan kök değerler; adalet, dostluk, dürüstlük, öz denetim, sabır, saygı, sevgi, sorumluluk, vatanseverlik, yardımseverlik olarak belirtilmiştir (MEB, 2018).

İlkokul öğrencilerinin eğitim öğretim yıllarında karşılaşmış oldukları ilk mihver derslerden olan Hayat Bilgisi dersinin öğrencilere değerleri kazandırmada önemini ortaya koyan ifadeler dikkatte alındığında, Hayat Bilgisi öğretim programı kazanımlarında değerlerin nasıl ve ne düzeyde yer aldığının araştırılması önemli görülmektedir. Bu önem doğrultusunda 2018 yılında yenilenen Hayat Bilgisi dersi öğretim programı kazanımlarında Hayat Bilgisi dersi öğretim programında yer alan kök değerlerin nasıl ve ne düzeyde yer aldığ oluşturmaktadır.

Alan yazında öğretim programı içerisinde belirtilen kök değerlerin 6-10 yaş çocuk öykü kitaplarında (Kurt, 2019) ve çizgi filmlerde (Bölük, 2018)nasıl ve ne düzeyde yer aldığını inceleyen araştırmalar mevcuttur. Alan yazın taraması yapıldığında değerler eğitimi, Hayat Bilgisi dersi öğretim programı ile değerler eğitimi ilişkisi üzerine yapılan araştırmalar da bulunmaktadır (Avcı ve Kayabaşı, 2018; Balık, 2016; Candan ve Ergen, 2014; Esemen ve Sadioğlu, 2019; Gözel, 2018; Kılınç ve Ersoy, 2013; Yaşaroğlu, 2018). Avcı ve Kayabaşı (2018) 1936 ve 2018 yılları arası hazırlanarak uygulamaya geçirilen, sekiz adet Hayat Bilgisi öğretim programlarının amaçlarındaki değerleri incelemişlerdir. Araştırma sonucuna göre 
2015 ve 2018 Hayat Bilgisi öğretim programındaki amaçlarda diğer programlara göre değerler genel ifadelerle yer almıştır. Candan ve Ergen (2014) Hayat Bilgisi dersi 3. Sınıf ders kitabındaki evrensel değerlerin nasıl ve ne düzeyde olduğunu tespit etmeye çalışmışlardır. Araştırma sonucuna göre incelenen Hayat Bilgisi ders kitabının içeriğinde yeterli düzeyde evrensel değer olduğu tespit edilmiştir. Kılınç ve Ersoy (2013) Hayat Bilgisi öğretim programının öğrencilerde etik bilinci oluşturma bakımından yeterliliğini sınıf öğretmenleri görüşlerine göre incelemişlerdir. Araştırma sonucunda Hayat Bilgisi öğretim programının öğrencilerde etik bilinci geliştirme konusunda yeterli olduğu tespit edilmiştir. Yaşaroğlu (2018) ise 1926 yılından 2018 yılına kadar uygulamaya konan Hayat Bilgisi öğretim programlarında değer ifadelerinin nasıl yer aldığını belirlemeyi amaçlamıştır. Araştırma sonucuna göre tüm programlarda belli ölçüde değer ifadelerinin olduğu fakat 2015, 2017 ve 2018 Hayat Bilgisi öğretim programlarında değerlerin daha açık bir şekilde yer aldığı tespit edilmiştir. Bu araştırmayı diğer araştırmalardan ayıran özellik Hayat Bilgisi öğretim programı kazanımlarının yine Hayat Bilgisi öğretim programında yer alan kök değerler açısından incelenmesidir. Bu doğrultuda araştırmanın problem cümleleri: 2018 yılında yenilenen Hayat Bilgisi öğretim programı kazanımlarında öğretim programında belirtilen kök değerler (adalet, dostluk, dürüstlük, öz denetim, sabır, saygı, sevgi, sorumluluk, vatanseverlik, yardımseverlik) nasıl ve ne düzeyde yer almaktadır? Hayat Bilgisi öğretim programı kazanımları ile ilişkili kök değerler sınıflar düzeyinde ve temalar düzeyinde nasıl bir dağılım göstermiştir?

\section{Yöntem}

Nitel bir çalışma olan bu araştırmada doküman analizi yöntemi kullanılmış olup analitik araştırma deseni ile araştırma gerçekleştirilmiştir. Doküman analizi yöntemi araştırmaya konu olan olay ve olgular hakkında bilgilerin yer aldığı yazılı ve görsel materyallerin incelenmesidir (Yıldırım ve Şimşek, 2013). McMillan (2004) göre analitik araştırmalarda araştırmanın materyali olan belgelerin, kayıtların ve dokümanların içeriği; olaylara, kavramlara, görüşlere, düşüncelere ve eserlere göre analiz edilir (akt, Ersoy, 2015). Öğretim programları eğitim bilimleri alanında yapılan araştırmalarda araştırmanın dokümanı olarak kullanılabilir (Şimşek, 2009). Bu araştırmadaki doküman2018 Hayat Bilgisi dersi öğretim programıdır. 2018 Hayat bilgisi dersi öğretim programı analitik araştırma deseninin doğasına göre öğretim programı içeriğinde belirtilen kök değer ifadelerine göre incelenmiştir.

Araştırmanın veri kaynağı Talim Terbiye Kurulu Başkanlığı internet sitesinde (http://mufredat.meb.gov.tr/Programlar.aspx) yer alan Hayat Bilgisi dersi öğretim programı 1, 2. ve 3. sınıf kazanımlarıdır.

\section{Veri Toplama Araçları}

Araştırmanın veri toplama aracı 2019 Hayat Bilgisi dersi öğretim programı içeriğinde yer alan "Değerlerimiz" başlığı altında ifade edilen kök değerlerdir 
(adalet, dostluk, dürüstlük, öz denetim, sabır, saygı, sevgi, sorumluluk, vatanseverlik, yardımseverlik).

\section{Verilerin Analizi, Geçerlik ve Güvenirlik}

Nitel araştırma doküman analizi yöntemi ile gerçekleştirilmiştir. Doküman analizi yöntemi araştırmaya konu olan olay ve olgular hakkında bilgilerin yer aldığı yazılı ve görsel materyallerin incelenmesidir (Yıldırım ve Şimşek, 2013). Bu süreç beş aşamadan oluşur: araştırmaya konu olan dokümanlara ulaşma, dokümanların özgünlüğünün kontrol edilmesi, dokümanların anlaması, dokümanların verilerinin analiz edilmesi ve son olarak verilerin kullanılması (Forster, 1995,akt. Yıldırım ve Şimşek, 2013).

$\mathrm{Bu}$ doğrultuda araştırmanın veri toplama ve çözümleme süreci şu şekilde gerçekleşmiştir: Araştırmanın veri kaynağı olan Hayat Bilgisi dersi öğretim programı 1, 2, ve 3. sınıf kazanımlarına Talim Terbiye Kurulu Başkanlığı internet sitesinde (http://mufredat.meb.gov.tr/Programlar.aspx) yer alan "Yenilenen Öğretim Programları" linkinden ulaşılmıştır. İlgili kurumun internet sitesinden ulaşıldı̆̆ı için veri kaynağı güvenilir ve orijinaldir. Veri kaynağındaki kazanımlarla ilişkili kök değerleri tespit edebilmek için kök değerlerin yer aldığı değer inceleme formu düzenlenmiştir. Öğretim programındaki kazanımlardaki değerler bu form yardımı ile incelenmiştir. Kazanımlarda ifade edilen değerler tespit edilmiştir. Her sınıf düzeyinde (1, 2. ve 3.sınıf), öğretim programındaki kazanım kodları kullanılarak, kazanımlar kök değerlerle eşleştirilmiştir. Değer inceleme formu ile araştırmacıdan bağımsız olarak alanında 25 yıl tecrübesi olan bir sınıf öğretmeni öğretim programındaki kazanımları incelemiştir. Araştırmacı ve sınıf öğretmeninin incelemesi sonucu ortaya çıkardıkları kodlar Miles ve Huberman (1994) güvenirlik formülü (Güvenirlik Katsayısı= Üzerinde görüş birliği sağlanan konu/terim sayısı (Üzerinde görüş birliği sağlanan konu/terim sayısı+ üzerinde görüş birliği bulunmayan konu/terim sayısı) × 100) ile hesaplanarak araştırmanın güvenirliği \%95 olarak belirlenmiştir.

\section{Bulgular}

Tablo 1. Hayat Bilgisi 1.Sını Öğretim Programında yer alan "Kök Değerler" ile ilişkili kazanımların tema ve kazanımlara göre dağılımı

\begin{tabular}{llll}
\hline Kök Değer & Tema & Kazanım Numaraları & Kazanım Sayısı \\
\hline Adalet & - & - & - \\
\hline Dostluk & Okulumuzda Hayat & HB.1.1.1. & 1 \\
\hline Dürüstlük & - & - & - \\
\hline Öz Denetim & - & - & - \\
\hline Sabır & - & - & - \\
\hline Sevgi & Okulumuzda Hayat, & HB.1.1.16., HB.1.2.2., HB.1.6.1., & 5 \\
\hline
\end{tabular}




\begin{tabular}{|c|c|c|c|}
\hline & $\begin{array}{l}\text { Evimizde Hayat, Doğada } \\
\text { Hayat }\end{array}$ & HB.1.6.2., HB.1.6.3. & \\
\hline Sayg1 & $\begin{array}{l}\text { Okulumuzda Hayat, } \\
\text { Evimizde Hayat, Ülkemizde } \\
\text { Hayat }\end{array}$ & $\begin{array}{l}\text { HB.1.1.2., HB.1.1.13., HB.1.2.2., } \\
\text { HB.1.2.4., HB.1.5.4. }\end{array}$ & 5 \\
\hline Sorumluluk & $\begin{array}{l}\text { Okulumuzda Hayat, } \\
\text { Evimizde Hayat, Sağlıklı } \\
\text { Hayat, Güvenli Hayat, }\end{array}$ & $\begin{array}{l}\text { HB.1.1.3., HB.1.1.8., HB.1.1.11., } \\
\text { HB.1.1.12., HB.1.1.14., } \\
\text { HB.1.1.15., HB.1.2.5., HB.1.2.6. } \\
\text {, HB.1.3.1., HB.1.3.2.,HB.1.3.4., } \\
\text { HB.1.3.5., HB.1.3.6., HB.1.3.7., } \\
\text { HB.1.4.1., HB.1.4.3., HB.1.4.6. }\end{array}$ & 17 \\
\hline Vatanseverlik & $\begin{array}{l}\text { Okulumuzda Hayat, } \\
\text { Ülkemizde Hayat }\end{array}$ & $\begin{array}{l}\text { HB.1.1.5., HB.1.1.6., HB.1.5.2., } \\
\text { HB.1.5.3., HB.1.5.4., HB.1.5.5., } \\
\text { HB.1.5.6., HB.1.5.7. }\end{array}$ & 8 \\
\hline Yardımseverlik & $\begin{array}{l}\text { Okulumuzda Hayat, } \\
\text { Evimizde Hayat }\end{array}$ & HB.1.1.10., HB.1.2.2. & 2 \\
\hline
\end{tabular}

Tablo 1 incelendiğinde Hayat Bilgisi öğretim programı kazanımları ile ilişkili değerler sıralanacak olursa "Sorumluluk" değeri ile ilgili 17, "Vatanseverlik" ile ilgili sekiz, "Sevgi" değeri ile ilgili beş, "Sayg1" değeri ile ilgili beş, "Yardımseverlik" değeri ile ilgili iki ve son olarak "Dostluk" değeri ile ilgili bir kazanım bulunmaktadır. Tablo 1 de görüldüğü gibi "Adalet”, “Dürüstlük”, "Öz denetim” ve "Sabır" değerleri ile ilgi Hayat Bilgisi 1. Sınıf öğretim programı içeriğinde kazanım bulunamamıştır.

Tablo 2. Hayat Bilgisi 1. Sını Öğretim Programı ünitelerinde yer alan kök değgerler

\begin{tabular}{|c|c|}
\hline Ünite Ad1 & Ünitede Yer Alan Kazanımlarla ilişkili Kök Değer \\
\hline “Okulumuzda Hayat" & $\begin{array}{l}\text { "Dostluk", "Sevgi", "Sayg1", "Sorumluluk" ve } \\
\text { "Yardımseverlik" }\end{array}$ \\
\hline "Evimizde Hayat" & $\begin{array}{l}\text { "Sevgi", "Saygi", "Sorumluluk" ve } \\
\text { "Yardımseverlik" }\end{array}$ \\
\hline “Doğada Hayat" & "Sevgi" \\
\hline “Ülkemizde Hayat" & "Sayg1" ve "Vatanseverlik" \\
\hline "Sağlıklı Hayat" & "Sorumluluk" \\
\hline “Güvenli Hayat” & "Sorumluluk" \\
\hline
\end{tabular}

Tablo 2 incelendiğinde Okulumuzda Hayat" ünitesi olan kazanımlarının "Dostluk", "Sevgi", "Sayg1", "Sorumluluk" ve "Yardımseverlik" değerleri ile ilişkili olduğu görülmektedir. "Sevgi", "Sayg1", "Sorumluluk" ve "Yardimseverlik" değerlerinin "Evimizde Hayat" ünitesi içerisinde olan kazanımlarla ilişkili olduğu, "Doğada Hayat" ünitesi içerisindeki kazanımların "Sevgi" değeri ile ilişkili olduğu, 
"Ülkemizde Hayat" ünitesi içerisindeki kazanımların "Sayg1" ve "Vatanseverlik" değerleri ile ilişkili olduğu ve son olarak "Sağlıklı Hayat" ve "Güvenli Hayat" ünitelerinin içerisindeki kazanımların "Sorumluluk" değeri ile ilişkili olduğu görülmektedir. Hayat Bilgisi öğretim programı içeriğindeki "Okulumuzda Hayat”, "Evimizde Hayat", "Doğada Hayat", "Ülkemizde Hayat", "Sağlıkl1 Hayat" ve "Güvenli Hayat" üniteleri kazanımlarının kök değerlerle ilişkili olduğu görülmektedir.

"Sorumluluk" değeri ile ilişkili kazanıma "Sağlıklı Hayat" ünitesinde yer alan "Kişisel bakımını düzenli olarak yapar." kazanımı ve bu kazanımın "El, yüz yıkama ve dişleri usulüne uygun olarak firçalama, banyo yapma, saç tarama, tuvalet eğitimi ile günlük kıyafetlerini giyme ve özenli kullanma üzerinde durulur." açıklaması örnek olarak gösterilebilir. "Vatanseverlik" değeri ile ilişkili kazanıma "Ülkemizde Hayat" ünitesi "Ülkemizin genel özelliklerini tanır." Kazanımı ve bu kazanımın "Ülkemizin adı, başkenti, İstiklâl Marşı ve Türk bayră̆ı tanıtılır. Bayrağımızın şekli ile ay ve yıldıza vurgu yapılarak rengi belirtilir." açıklaması örnek olarak gösterilebilir. "Sevgi" değeri ile ilişkili kazanıma "Evimizde Hayat" ünitesi "Aile hayatının önemini kavrar." kazanımı ve bu kazanımın "Aileyi bir arada tutan değerlerle (sevgi, saygl, bă̆hllık, şefkat, vefa vb.) aile içi iş birliği ve dayanışmanın aile düzenine katkıları üzerinde durulur." açıklaması örnek olarak gösterilebilir. Bu açıklama doğrultusunda bu kazanımın "Sayg1 ve yardımseverlik" değerleri ile de ilişkili olduğu görülmektedir.

Tablo 3.2.Sınıf Hayat Bilgisi Öğretim Programı yer alan "Kök Değgerler" ile ilişkili kazanımların tema ve kazanımlara göre dağılımı

\begin{tabular}{llll}
\hline Kök Değer & Tema & Kazanım Numaraları & Kazanım Sayısı \\
\hline Adalet & Okulumuzda Hayat & HB.2.1.7. & 1 \\
\hline Dostluk & Okulumuzda Hayat & HB.2.1.7. & 1 \\
\hline Dürüstlük & Okulumuzda Hayat & HB.2.1.7. & 1 \\
\hline Öz Denetim & Okulumuzda Hayat & HB.2.1.1., HB.2.1.7., HB.2.1.8., HB.2.1.10. & 4 \\
\hline Sabır & Okulumuzda Hayat & HB.2.1.7. & 1 \\
\hline Sevgi & Okulumuzda Hayat, & HB.2.1.7., HB.2.2.2. & 2 \\
& Evimizde Hayat & & \\
\hline Saygı & Okulumuzda Hayat, & HB.2.1.2., HB.2.1.7., HB.2.1.10., HB.2.2.2., & 5 \\
& Evimizde Hayat, & HB.2.5.7. & \\
& Sağlılı Hayat, & & 15 \\
& Ülkemizde Hayat & & \\
\hline Sorumluluk & Okulumuzda Hayat, & HB.2.1.3., HB.2.1.6., HB.2.1.7., HB.2.1.11., & \\
& Evimizde Hayat, & HB.2.2.4., HB.2.2.6., HB.2.2.8., HB.2.2.9., & \\
& Sağlılı Hayat, & HB.2.3.2., HB.2.3.3., HB.2.3.4., HB.2.3.7., & \\
& Güvenli Hayat & HB.2.4.2., HB.2.4.5., HB.2.4.6. & \\
\hline Vatanseverlik & Ülkemizde Hayat & HB.2.5.1.,HB.2.5.2.,HB.2.5.3.,HB.2.5.4.,HB. & 6 \\
& & $2.5 .5 ., H B .2 .5 .6$. & \\
\hline
\end{tabular}




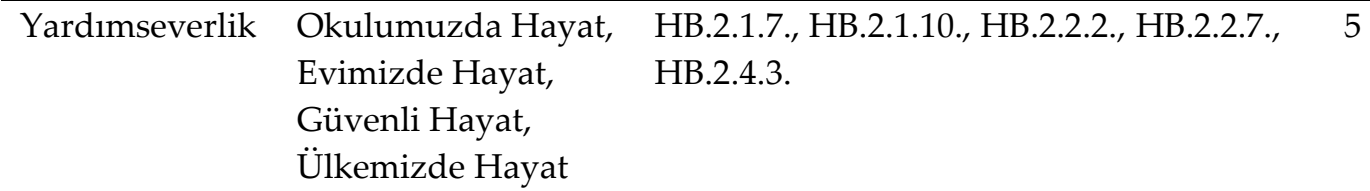

Tablo 3'te "Sorumluluk" değeri ile ilişkili 15, "Vatanseverlik" değeri ile ilişkili altı, "Yardımseverlik" ve "Sayg1" değerleri ile ilişkili beş, "Öz denetim" değeri ile ilişkili dört, "Sevgi" değeri ile ilişkili iki ve de "Adalet", "Dostluk", "Dürüstlük" "Sabır" değerleri ile ilişkili birer kazanım bulunmaktadır. Hayat Bilgisi dersi 2. Sınıf öğretim programı kazanımlarının "kök değerler" in tümüyle ilişkili olduğu görülmektedir. Tablo incelendiğinde "HB.2.1.7.", “HB.2.1.10." ve "HB.2.2.2" numaralı kazanımların birden fazla değerler ilişkili olduğu görülmektedir.

Tablo 4. Hayat Bilgisi 2. Sını Öğretim Programı ünitelerinde yer alan kök değgerler

\begin{tabular}{ll}
\hline Ünite Adı & Ünitede Yer Alan Kazanımlarla ilişkili Kök Değer \\
\hline Okulumuzda Hayat & $\begin{array}{l}\text { Adalet, Dostluk, Dürüstlük, Sabır, Sevgi, Saygı, } \\
\text { Sorumluluk, Yardımseverlik }\end{array}$ \\
\hline Evimizde Hayat & Sevgi, Saygı, Sorumluluk, Yardımseverlik \\
\hline Sağlıklı Hayat & Saygı, Sorumluluk \\
\hline Ülkemizde Hayat & Saygı, Vatanseverlik, Yardımseverlik \\
\hline Güvenli Hayat & Sorumluluk, Yardımseverlik \\
\hline
\end{tabular}

Tablo 4 incelendiğinde Hayat Bilgisi 2. sinıf öğretim programı ünitelerinden "Okulumuzda Hayat" ünitesinin sekiz, "Evimizde Hayat" ünitesinin dört, "Ülkemizde Hayat" ünitesinin üç, "Güvenli Hayat" ünitesinin iki ve son olarak "Sağlıklı Hayat" ünitesinin iki kök değerle ilişkili olduğu görülmektedir.

"Sorumluluk" değeri ile ilişkili kazanıma "Okulumuzda Hayat" ünitesi "Okulda arkadaşlarıyla oyun oynarken kurallara uyar." örnek gösterilebilir. Bu kazanım "Oyun oynarken arkadaşlarına karşı nezaket dili kullanma, iş birliği içinde olma, öfkesini kontrol etme, arkadaşlarına zarar vermeme, oyunu kazanma veya kaybetmenin doğal bir durum olması gibi konular üzerinde durulur." Açılaması doğrultusunda "Sayg1", "Yardımseverlik", ve "Öz denetim" değerleri ile de ilişkilidir. "Yardımseverlik" değeri ile ilişkili kazanıma "Evimizde Hayat" ünitesi "Akrabalık ilişkilerinin önemini kavrar." kazanımı ve bu kazanımın "Akrabaları bir arada tutan değerlerle (sevgi, saygı, bağhllık, şefkat, vefa vb.), iş birliği ve dayanışmanın akrabalık ilişkilerine katkıları üzerinde durulur" açılaması doğrultusunda örnek gösterilebilir. Kazanım açıklaması incelendiğinde bu kazanımın "Sevgi" ve "Saygı" değerleri ile de ilişkili olduğu görülmektedir. "Öz denetim" değeri ile ilişkili "Okulumuzda Hayat" ünitesi "Okulda arkadaşlarıyla oyun oynarken kurallara uyar." Kazanımının "Oyun oynarken arkadaşlarına karşı nezaket dili kullanma, iş birliği içinde olma, öfkesini kontrol etme, arkadaşlarına zarar vermeme, oyunu kazanma veya kaybetmenin doğal bir durum 
olması gibi konular üzerinde durulur." açıklaması doğrultusunda kök değerlerle ilişkili olduğu örnek gösterilebilir. Açıklama incelendiğinde öğrencilerin öfkelerini kontrol etmeleri konusunda durulması gerektiği ifade edilmiştir.

Tablo 5.Hayat Bilgisi3.Sınf Öğretim Programı yer alan "Kök Değerler" ile ilişkili kazanımların tema ve kazanımlara göre dağılımı

\begin{tabular}{lllc}
\hline Kök Değer & Tema & Kazanım Numaraları & Kazanım Sayısı \\
\hline Adalet & Okulumuzda Hayat, & HB.3.1.8. & 1 \\
\hline Dostluk & Okulumuzda Hayat, & HB.3.1.4. & 1 \\
\hline Dürüstlük & Okulumuzda Hayat & HB.3.1.4. & 1 \\
\hline Öz Denetim & Okulumuzda Hayat & HB.3.1.1., HB.3.1.2., HB.3.1.3. & 3 \\
\hline Sabır & - & - & - \\
\hline Sevgi & - & - & - \\
\hline Saygı & Okulumuzda Hayat & HB.3.1.4. & 1 \\
\hline Sorumluluk & Evimizde Hayat, Sağlılı & HB.3.2.2., HB.3.2.4., HB.3.2.6., & 16 \\
& Hayat, Güvenli Hayat, & HB.3.2.7., HB.3.2.8., HB.3.3.1., & \\
& Ülkemizde Hayat, & HB.3.3.2., HB.3.3.3., HB.3.3.4., & \\
& Doğada Hayat, & HB.3.3.5., HB.3.4.2., HB.3.4.3., & \\
& Ülkemizde Hayat & HB.3.4.6., HB.3.4.7., HB.3.5.4., & \\
\hline Yardımseverlik & Okulumuzda Hayat & HB.3.1.4., HB.3.1.7. & \\
\hline & & HB.3.5.5., HB.3.6.5. & \\
\hline Vatanseverlik & Ülkemizde Hayat & HB.3.5.2., HB.3.5.3., HB.3.5.4.,, & \\
& & HB.3.5.2., HB.3.5.2.,HB.3.5.2., & \\
& & HB.3.5.6., HB.3.5.8., HB.3.5.9. & \\
\end{tabular}

Tablo 5 incelendiğinde Hayat Bilgisi öğretim programı kazanımları ile ilişkili değerler sıralanacak olursa "Sorumluluk" değeri ile ilgili 16, "Vatanseverlik" değeri ile ilgili dokuz, "Öz Denetim" değeri ile ilgili üç, "Yardımseverlik" değeri ile ilgili iki ve "Adalet", "Dostluk", "Dürüstlük", "Sayg1" değerleri ile ilgi birer kazanım bulunmaktadır. Tabloda “HB.3.1.4."ve “HB.3.5.4” numaralı kazanımların birden fazla değerle ilgili olduğu görülmektedir.

Tablo 6. Hayat Bilgisi 3. Sinı Öğretim Programı ünitelerinde yer alan kök değerler

\begin{tabular}{ll}
\hline Ünite Adı & Ünitede Yer Alan Kazanımlarla ilişkili Kök Değer \\
\hline Okulumuzda Hayat & $\begin{array}{l}\text { Adalet, Dostluk, Dürüstlük, Öz Denetim, } \\
\text { Saygı, Yardımseverlik }\end{array}$ \\
\hline Evimizde Hayat & Sorumluluk \\
\hline Sağlıklı Hayat & Sorumluluk \\
\hline Güvenli Hayat & Sorumluluk \\
\hline
\end{tabular}




\begin{tabular}{ll}
\hline Ülkemizde Hayat & Vatanseverlik, Sorumluluk \\
\hline Doğada Hayat & Sorumluluk \\
\hline
\end{tabular}

Tablo 6' da görüldüğ̈ü gibi hayat Bilgisi 3. Sınıf öğretim programı ünitelerinden "Okulumuzda Hayat" ünitesi altı, Ülkemizde Hayat ünitesi iki ve "Evimizde Hayat", "Sağliklı hayat", "Güvenli Hayat", "Doğada Hayat" üniteleri birer kök değerle ilişkilidir.

"Adalet" değeri ile ilgili kazanıma "Okulumuzda Hayat" ünitesi "Okula ilişkin istek ve ihtiyaçlarını okul ortamında demokratik yollarla ifade eder." kazanımı örnek gösterilebilir. Bu kazanımın nezaket kurallarına uyarak kendini ifade etme açıklaması da bu kazanımı "Saygı" değeri ile ilgili kılmaktadır. "Dostluk" değeri ile ilgili kazanıma "Okulumuzda Hayat" ünitesi "Arkadaşlık sürecinde dikkat edilmesi gereken hususları kavrar." kazanımı örnek olarak gösterilebilir. Bu kazanımdaki "Arkadaşlı bağlarmın oluşturulması, korunması, güçlendirilmesi ve dostluğa dönüştürülmesine aracı olacak tutum ve değerlerin (sayg, dayanışma, birbirinin sorunlarına karşı duyarlllık, karşıllklı zarafet, güven ve kibarlı vb.) üzerinde durulur." İfadesi bu kazanımı "Sayg1", "Yardımseverlik" ve "Dürüstlük" değerleri ile ilgili kılmaktadır.

Tablo 7. Hayat Bilgisi Öğretim Programı kazanımları ile ilişkili kök değgerlerin sınıflar düzeyinde dă̆ılımı

\begin{tabular}{ll}
\hline Sınıf Düzeyi & İlişkili Kök Değer \\
\hline 1. Sınıf & $\begin{array}{l}\text { Dostluk, sevgi, saygı, sorumluluk, vatanseverlik, } \\
\text { yardımseverlik }\end{array}$ \\
\hline 2. Sınıf & $\begin{array}{l}\text { Adalet, dostluk, dürüstlük, öz denetim, sabır, sevgi, } \\
\text { saygı, vatanseverlik, yardımseverlik }\end{array}$ \\
\hline 3. Sınıf & $\begin{array}{l}\text { Adalet, dostluk, dürüstlük, öz denetim, saygı, } \\
\text { sorumluluk, vatanseverlik, yardımseverlik }\end{array}$ \\
\hline
\end{tabular}

Tablo 7'ye göre öğretim programında yer alan dokuz kök değerden altı kök değer (Dostluk, sevgi, saygı, sorumluluk, vatanseverlik, yardımseverlik) 1. sınıf kazanımları ile ilişkilidir. 2. sınıf Hayat Bilgisi öğretim programı kazanımları ile ise adalet, dostluk, dürüstlük, öz denetim, sabır, sevgi, sayg1, vatanseverlik, yardımseverlik olmak üzere öğretim programında belirtilen dokuz kök değerin tümü ilişkilidir. Son olarak 3. Sınıf Hayat Bilgisi dersi öğretim programı kazanımları ile adalet, dostluk, dürüstlük, öz denetim, saygı, sorumluluk, vatanseverlik ve yardımseverlik kök değerleri ilişkili olup sekiz kök değer kazanımlarla ilişkilidir.

Genel olarak, Hayat Bilgisi dersi öğretim programı kazanımlarının kök değerlerle ilişkisi incelendiğinde "Sorumluluk" değerinin kazanımla ilişkisinin tüm sınıf düzeylerinde yüksek olduğu görülmektedir. " "Sorumluluk" değerinden sonra Vatanseverlik" değerinin kazanımlarla ilişkisinin tüm sınıf düzeylerinde yüksek 
olduğu da görülmektedir. Kazanımların altında yer alan kazanım açıklamaları doğrultusunda Hayat Bilgisi öğretim programı kazanımlarından bazılarının birden fazla değerle ilgili olduğu görülmektedir.

\section{Sonuç ve Tartışma}

Hayat Bilgisi dersinin, öğrencilerin yakın çevresine sağlıklı bir şekilde uyum sağlamasını ve bu çevrede aktif bir şekilde rol almasını sağlayan, önemli bir ders olduğu düşünülmektedir. Bireylerin çevresine uyumunu sağlayan unsurlardan biri de bireyin o toplumdaki değerleri davranışa dönüştürmesidir. Hayat Bilgisi dersi de öğrencilere bu değerleri kazandıracak, eğitim öğretim yıllarında öğrencilerin ilk karşılaşmış oldukları dersidir. İlkokul Hayat Bilgisi dersi 1, 2. ve 3. sınıf öğretim programı kazanımlarının öğretim programı içerisinde yer alan "kök değerler" ile ilişkisinin nasıl, ne düzeyde ve de temalar düzeyinde nasıl dağılım gösterdiğini belirlemeyi amaçlayan bu araştırma sonucuna göre sınıflar düzeyinde kazanımlarla en fazla ilişkili olan kök değerin sorumluluk ve vatanseverlik olduğu sonucuna ulaşılmıştır.

İlkokul 1. sınıf Hayat Bilgisi dersi öğretim programı "Okulumuzda Hayat" ünitesinin beş, "Evimizde Hayat" ünitesinin dört, "Ülkemizde Hayat" ünitesinin iki, "Doğada Hayat", "Sağlıklı Hayat" ve "Güvenli Hayat" ünitelerinin birer kök değerle ilişkili olduğu sonucuna ulaşılmıştır. Bu sonuca göre İlkokul Hayat Bilgisi dersi 1. sınıf öğretim programı ünitelerinde "kök değerler" in dengeli bir şekilde dağılmadığı anlaşılmaktadır. İlkokul Hayat Bilgisi dersi 2. sınıf öğretim programı "Okulumuzda Hayat" ünitesinin sekiz, "Evimizde Hayat" ünitesinin dört, "Ülkemizde Hayat" ünitesinin üç, "Sağlıklı Hayat" ve "Güvenli Hayat" ünitesinin ikişer kök değerle ilişkili olduğu sonucuna ulaşılmıştır. Hayat Bilgisi dersi 2. sınıf öğretim programı ünitelerinde kök değerlerin 1. Sınıf Hayat Bilgisi öğretim programına göre daha dengeli dağıldığı anlaşılmaktadır. Fakat Hayat Bilgisi dersi 1. Sınıf öğretim programı ünitelerinin tamamının "Kök değerlerle" ilişkili olduğu, Hayat Bilgisi dersi 2. sınıf öğretim programı ünitelerinin ise beşinin "Kök değerlerle" ilişkili olduğu sonucu ortaya çıkmaktadır. Hayat Bilgisi dersi 2. sınıf öğretim programı ünitelerinden "Doğada Hayat" ünitesinin "Kök değerler" ile ilişkili yoktur. İlkokul Hayat Bilgisi dersi 3. sınıf öğretim programı "Okulumuzda Hayat" ünitesinin altı, "Ülkemizde Hayat" ünitesinin iki ve "Evimizde Hayat", "Sağlıklı Hayat", "Güvenli Hayat", "Doğada Hayat" ünitelerinin birer "Kök değer" ile ilişkili olduğu sonucuna ulaşılmıştır. Bu sonuca göre İlkokul Hayat Bilgisi dersi 3. sınıf öğretim programında "Kök değerler"in dengeli bir şekilde dağılmadığı ifade edilebilir.

Hayat Bilgisi 1. sınıf öğretim programı kazanımlarıyla altı, Hayat Bilgisi 2. sınıf öğretim programı kazanımlarıyla dokuz, Hayat Bilgisi 3. sınıf öğretim programı kazanımlarıyla sekiz kök değerin ilişkili olduğu sonucuna ulaşılmış olup "kök değerler"in sınıflar düzeyinde dengeli bir şekilde dağıldığı anlaşılmaktadır. Hayat Bilgisi öğretim programı kazanımlarının açıklamaları bulunmaktadır. Bu açıklamalar 
aracılığı ile kazanımları öğrencilere kazandırılırken nelere dikkat edileceği belirtilmiştir. Kazanım açıklamaları doğrultusunda kazanımlar değerlerle ilişkilendirilmiştir.

Kaymakçı (2016) 2009 Hayat Bilgisi öğretim programı içeriğinde değerlerin hangi kazanımlarla ilişkilendirilebileceğinin belirtildiği ve en fazla kazanımla ilişkili olan değerin "Vatanseverlik" değeri olduğunu ifade etmiştir. Yapılan bu araştırmada öğretim programı içeriğinde yer alan kazanımların hangi değerlerle ilişkilendirileceğinin belirtilmediği sonucuna ulaşılmıştır. Ayrıca bu araştırmada kazanımlarla en fazla "Sorumluluk" değerinin ilişkili olduğu sonucuna ulaşılmıştır. $\mathrm{Bu}$ farklılıkların nedeninin Kaymakçı (2016)'nın ifade ettiği Hayat bilgisi öğretim programı kazanımlarının (2009 Öğretim programı) ve bu araştırmada incelenen Hayat Bilgisi öğretim programı kazanımlarının (2019 öğretim programı) farklı olmasından kaynaklandı̆̆ı düşünülmektedir.

Candan ve Ergen (2014 ) yapmış oldukları çalışmada, 3. Sınıf Hayat Bilgisi ders kitabında en fazla "Sorumluluk ve sevgi" değerine yer verildiğini belirtmiştir. Bu araştırmada ise Hayat Bilgisi 3. Sınıf öğretim programı kazanımlarında en fazla "Sorumluluk ve vatanseverlik" değerine yer verildiği sonucuna ulaşılmıştır. "Sevgi" değeri ile ise Hayat Bilgisi 3. Sınıf öğretim programı kazanımlarında kazanım tespit edilememiştir. Candan ve Ergen'in (2014) yapmış oldukları çalışmanın dokümanı Hayat Bilgisi ders kitabı iken, bu araştırmanın dokümanı Hayat Bilgisi dersi öğretim programı kazanımlarıdır. Bu doğrultuda Hayat Bilgisi 3. sınıf öğretim programı kazanımlarında vurgulanan "Sorumluluk" değerinin Hayat Bilgisi 3. sinıf ders kitabında da vurgulandığı ifade edilebilir.

Gözel (2018) Hayat Bilgisi öğretim programında yer alan değerlerden "adalet, dürüstlük ve doğruluk" değerlerini, öğretmenlerin en çok önem verdikleri ve öğrencilerine kazandırılması gerektiğini düşündükleri değerler olduğunu belirtmiştir. Bu araştırmada "adalet, dürüstlük ve doğruluk" değerlerinin Hayat Bilgisi dersi öğretim programı kazanımlarında yeterli düzeyde bulunmadığı sonucuna ulaşılmıştır.

\section{Öneriler}

"Kök değerler" ile ilişkili Hayat Bilgisi öğretim programı kazanımları sayısı alan uzmanları görüşü doğrultusunda artırılabilir. İleri ki program hazırlama sürecinde Hayat Bilgisi dersi öğretim programı ünitelerinde "kök değerler" dengeli bir şekilde dağılım gösterilebilir. Ayrıca Hayat Bilgisi öğretim programı kazanımları ile ilgili açıklamalar artırılabilir. Hayat Bilgisi öğretim programı kazanımları ile ilişkisi olmayan "kök değerler" de program kazanımlarında yer verilebilir. İleriki araştırmalara yönelik ise Hayat Bilgisi öğretim programı kazanımlarının öğrencilere "kök değerler" i kazandırma düzeyi nicel bir araştırma ile araştırılabilir. Ayrıca Hayat Bilgisi öğretim programı kazanımları ile ilişkili "kök değerler" in Hayat bilgisi ders kitaplarında nasıl ve ne düzeyde yer aldığı araştırılabilir. 


\section{Etik Beyan}

“Hayat Bilgisi Öğretim Programı Kazanımlarının Kök Değerler ile İlişkisinin Değerlendirilmesi" başlıklı çalışmanın yazım sürecinde bilimsel, etik ve alıntı kurallarına uyulmuş; toplanan veriler üzerinde herhangi bir tahrifat yapılmamış ve bu çalışma herhangi başka bir akademik yayın ortamına değerlendirme için gönderilmemiştir.

\section{Kaynaklar}

Avcı, E. K., \& Kayabaşı, E. Z. (2018). Hayat bilgisi dersi öğretim programlarının amaçlarındaki değerlerin içerik analizi (1936-2018). Değerler Eğitimi Dergisi, 16(35), 27-56.

Aydın, M. Z., \& Gürler, Ş. (2014). Okulda değerler eğitimi. Ankara: Nobel Akademi Yayıncilik.

Bahçe, A. (2010). Hayat bilgisi öğretiminde değerlerin kazandırılma düzeylerinin öğretmen görüşlerine göre değerlendirilmesi. Yayınlanmamış yüksek lisans tezi, Selçuk Üniversitesi, Eğitim Bilimleri Enstitüsü, Konya.

Balık, Z. D. (2016). Hayat bilgisi öğretim programındaki değerler bağlamında hayat bilgisi ders kitapları ile yüz temel eser listesindeki ulusal masalların karşılaştırılması. Yayınlanmamış yüksek lisans tezi, Eğitim Bilimleri Enstitüsü, Yüzüncü Yıl Üniversitesi, Van.

Bölük, E. (2018). Çizgi filmlerde yer alan değerlerin ilkokul hayat bilgisi öğretim programında yer alan değerler çerçevesinde incelenmesi. Yayınlanmamış yüksek lisans tezi, Mustafa Kemal Üniversitesi, Eğitim Bilimleri Enstitüsü, Hatay.

Candan, G. D. \& Ergen, G. (2014). 3. Sınıf hayat bilgisi ders kitaplarını temel evrensel değerleri içermesi bakımından incelenmesi. Uşak Üniversitesi Sosyal Bilimler Dergisi,7(1), 134-161.

Ersoy, A. (2015). Doktora öğrencilerinin ilk nitel araştırma deneyimlerinin günlükler aracılığılya incelenmesi. Pegem Eğitim ve Öğretim Dergisi, 5(5), 549-568.

Esemen, A. \&Sadioğlu, Ö. (2019). 2018 tarihinde yenilenen hayat bilgisi öğretim programı kazanımlarında ulusal değerler. Academy Journal of Educational Sciences, 3(1), 1427.

Gözel, B. (2018). Hayat bilgisi dersi öğretim programının değerler eğitimi açısından öğretmen görüşlerine göre değerlendirilmesi. Yayınlanmamış yüksek lisans tezi, Aydın Adnan Menderes Üniversitesi, Eğitim Bilimleri Enstitüsü, Aydın.

Hökelekli, H. (2010). Modern eğitimde yeni bir paradigma: Değerler. Ĕğitimi Ĕ̆itime Bakış Dergisi, 18, 4-10.

Jacobs, D. T. \& Jacobs-Spencer, J. (2001). Teaching virtues: Building character across the curriculum. Scarecrow Press. 
Kılınç, M. \& Ersoy, A. (2013). Hayat bilgisi dersi öğretim programının etik bilinç geliştirme açısından öğretmen görüşlerine dayalı olarak değerlendirilmesi. Mersin Üniversitesi Ĕ̆itim Fakültesi Dergisi, 9(2), 109-126.

Kurt, Ö. (2019). 6-10 Yaş çocuk öykü kitaplarının MEB 2018 hayat bilgisi öğretim programında bulunan değerler yönünden incelenmesi. Yayınlanmamış yüksek lisans tezi, Dokuz Eylül Üniversitesi, Eğitim Bilimleri Enstitüsü, İzmir.

Milli Eğitim Bakanlığı, (2019). 2019 Hayat Bilgisi öğretim programı. Ankara.

Özdemir, S. M. (2009). Eğitimde program değerlendirme ve Türkiye' de eğitim programlarını değerlendirme çalışmalarının incelenmesi. Yüzüncü Yıl Üniversitesi Eğitim Fakültesi Dergisi, 6(2), 126-149.

Raths, L. E., Harmin, M. \& Simon, S. B. (1966). Values and teaching: Working with values in the classroom. Ohio: Charles E. Merrill Books Inc.

Şahin, M. (2009). Cumhuriyetin kuruluşundan günümüze Türkiye'de Hayat Bilgisi dersi programlarının gelişimi. Journal of International Social Research, 2(8), 402-410.

Şimşek, H. (2009). Eğitim tarihi araştırmalarında yöntem sorunu. Ankara Üniversitesi Ĕ̆itim Bilimleri Fakültesi Dergisi , 42 (1), 35-51.

Topses, G., Güçlü, N., Yel, S., Korkmaz, A., Çakmak, M., Köksal, H.,\& Albayrak, F. (2001). Konu alanı ders kitabı inceleme kılavuzu hayat bilgisi1-3. Ankara: Nobel Yayın Dağıtım.

Turan, R. \& Ulusoy, K. (2016). Farklı yönleriyle değerler eğitimi. İçinde Kaymakçı, S. Hayat bilgisinde değerler eğitimi. Ankara: Pegem Akademi Yayıncılık.

Turan, R. \& Ulusoy, K. (2014). Farklı yönleriyle değerler eğitimi. Ankara: PegemA Akademi.

Ulusoy, K. \& Dilmaç, B. (2014). Değerler eğitimi. Ankara: Pegem Akademi.

Yaşaroğlu, C. (2019). Öğretim programlarında değerler: hayat bilgisi dersi örneği. Anemon Muş Alparslan Üniversitesi Sosyal Bilimler Dergisi, 6(5), 725-733.

Yaşar, Ş. , Kasa, B., \& Bayır, Ö. G. (2015). Sınıf öğretmeni adaylarının görüşlerine göre değerlerin ulusal ve evrensel olarak sınıflandırılması. TurkishStudies,10(3), 581600 .

Yıldırım, A. \& Şimşek, H. (2016). Sosyal bilimlerde nitel araştırma yöntemleri (11.Basım). Ankara: Seçkin Yayıncilık. 